\title{
Genetic basis for denitrification in Ensifer meliloti
}

\author{
Maria J Torres ${ }^{1}$, Maria I Rubia', Teodoro Coba de la Peña², José J Pueyo², Eulogio J Bedmar ${ }^{1}$ \\ and María J Delgado ${ }^{1 *}$
}

\begin{abstract}
Background: Denitrification is defined as the dissimilatory reduction of nitrate or nitrite to nitric oxide (NO), nitrous oxide $\left(\mathrm{N}_{2} \mathrm{O}\right)$, or dinitrogen gas $\left(\mathrm{N}_{2}\right) \cdot \mathrm{N}_{2} \mathrm{O}$ is a powerful atmospheric greenhouse gas and cause of ozone layer depletion. Legume crops might contribute to $\mathrm{N}_{2} \mathrm{O}$ production by providing nitrogen-rich residues for decomposition or by associating with rhizobia that are able to denitrify under free-living and symbiotic conditions. However, there are limited direct empirical data concerning $\mathrm{N}_{2} \mathrm{O}$ production by endosymbiotic bacteria associated with legume crops. Analysis of the Ensifer meliloti 1021 genome sequence revealed the presence of the napEFDABC, nirk, norECBQD and nosRZDFYLX denitrification genes. It was recently reported that this bacterium is able to grow using nitrate respiration when cells are incubated with an initial $\mathrm{O}_{2}$ concentration of 2\%; however, these cells were unable to use nitrate respiration when initially incubated anoxically. The involvement of the nap, nirk, nor and nos genes in E. meliloti denitrification has not been reported.
\end{abstract}

Results: E. meliloti nap, nirk and norC mutant strains exhibited defects in their ability to grow using nitrate as a respiratory substrate. However, E meliloti nosZ was not essential for growth under these conditions. The E. meliloti napA, nirk, norC and nos $Z$ genes encode corresponding nitrate, nitrite, nitric oxide and nitrous oxide reductases, respectively. The NorC component of the E. meliloti nitric oxide reductase has been identified as a $c$-type cytochrome that is $16 \mathrm{kDa}$ in size. Herein, we also show that maximal expression of the E. meliloti napA, nirk, norC and nos $Z$ genes occurred when cells were initially incubated anoxically with nitrate.

Conclusion: The E. meliloti napA, nirk, norC and nosZ genes are involved in nitrate respiration and in the expression of denitrification enzymes in this bacterium. Our findings expand the short list of rhizobia for which denitrification gene function has been demonstrated. The inability of E. meliloti to grow when cells are initially subjected to anoxic conditions is not attributable to defects in the expression of the napA, nirk, norC and nos $Z$ denitrification genes.

Keywords: Cu-containing nitrite reductase, Nitrate respiration, Nitric oxide reductase, Nitrous oxide reductase, Periplasmic nitrate reductase

\section{Background}

Denitrification is the respiratory reduction of nitrate or nitrite to the gaseous products nitric oxide (NO), nitrous oxide $\left(\mathrm{N}_{2} \mathrm{O}\right)$, or dinitrogen $\left(\mathrm{N}_{2}\right)$. $\mathrm{N}_{2} \mathrm{O}$ is a powerful greenhouse gas (GHG) that has a 300 -fold greater global warming potential than $\mathrm{CO}_{2}$ based on its radiative capacity and could persist for up to 150 years in the atmosphere [IPCC 2007, [1]]. In bacteria, the denitrification process requires four separate enzymatically catalysed reactions. The first

\footnotetext{
* Correspondence: mdelgado@eez.csic.es

${ }^{1}$ Estación Experimental del Zaidin, Consejo Superior de Investigaciones Científicas (CSIC), P.O. Box 419, 18080 Granada, Spain

Full list of author information is available at the end of the article
}

reaction in denitrification is the reduction of nitrate to nitrite, which is catalysed by a membrane-bound nitrate reductase (Nar) or a periplasmic nitrate reductase (Nap) (reviewed in [2-6]). In denitrifying bacteria, the reduction of nitrite to nitric oxide is catalysed by two types of respiratory Nir: the NirS $c d_{1}$ nitrite reductase, a homodimeric enzyme with haems $c$ and $d_{1}$, and NirK, a coppercontaining Nir [7-11]. Then, nitric oxide is reduced to nitrous oxide by three types of nitric oxide reductase (Nor), which are classified based on the nature of their electron donor as cNor, qNor or qCuANor (reviewed in $[4,9,10,12])$. The final step in denitrification consists of the two-electron reduction of nitrous oxide to dinitrogen gas. This reaction is performed by nitrous oxide reductase 
(Nos), a copper-containing homodimeric soluble protein located in the periplasmic space (reviewed in [9-11,13-15]). Bacteria of the order Rhizobiales, collectively referred to as rhizobia, are best known for their ability to establish $\mathrm{N}_{2}$-fixing symbiosis on legume roots and on the stems of some aquatic leguminous plants. In addition to fixing $\mathrm{N}_{2}$, many rhizobia species have enzyme-encoding genes for some or all of the four reductase reactions in denitrification. Several studies have reported that legume crops contribute to $\mathrm{N}_{2} \mathrm{O}$ production by providing $\mathrm{N}$ rich residues for decomposition [16] and by associating with some rhizobia that are able to denitrify under freeliving and under symbiotic conditions, producing $\mathrm{N}_{2} \mathrm{O}$ [17-19]. However, soybean endosymbiont Bradyrhizobium japonicum is the only rhizobia species for which it has been demonstrated that the napEDABC, nirK, nor $C B Q D$ and nosRZDYFLX genes are involved in complete denitrification $[17,19,20]$.

Ensifer (formerly Sinorhizobium) meliloti is a rhizobial species that establishes symbiotic $\mathrm{N}_{2}$-fixing associations with plants of the genera Medicago, Melilotus and Trigonella. Genes for the complete denitrification pathway are present in the E. meliloti pSymA megaplasmid [21,22]. Transcriptomic analyses have shown that the E. meliloti nap, nir, nor and nos genes are induced in response to $\mathrm{O}_{2}$ limitation [23]. Under these conditions, the expression of denitrification genes is coordinated via a two-component regulatory system, FixLJ, and via a transcriptional regulator, FixK [24]. Recent transcriptomic studies demonstrated that denitrification genes (nirK and norC) and other genes related to denitrification ( $a z u 1$, hemN, nnrU and $n n r S$ ) are also induced in response to $\mathrm{NO}$ and that the regulatory protein NnrR is involved in the control of this process [25]. In symbiotic association with $M$. truncatula plants, recent findings have demonstrated that the E. meliloti napA and nirK denitrification genes contribute to nitric oxide production in root nodules [26]. Although the regulation and symbiotic characterisation of E. meliloti denitrification genes is well understood, the roles of these genes in nitrate reduction through denitrification and in the emission of $\mathrm{N}_{2} \mathrm{O}$ are not known.
Recent results from our group [21] reported the capability of E. meliloti to use nitrate or nitrite as respiratory substrates when cells were incubated with an initial oxygen concentration of $2 \%$; however, nitrate and nitrite could not be used as respiratory substrates when the cells were initially incubated anoxically. In the present work, functional analyses of the E. meliloti napA, nirK, $n o r C$ and nos $Z$ genes reveal their involvement in the ability of E. meliloti to grow using nitrate as a respiratory substrate and in the expression of denitrification enzymes.

\section{Results}

Nitrate-dependent growth of E. meliloti napA, nirK, norC and nos $Z$ mutants

To investigate the involvement of denitrification genes in the ability of E. meliloti to grow using nitrate as an electron acceptor, the wild-type strains 1021 and 2011 and napA, nirK, nor $C$ and nos $Z$ mutant strains (Table 1) were incubated in minimal medium (MM) supplemented with $10 \mathrm{mM} \mathrm{KNO}_{3}(\mathrm{MMN})$ with an initial $\mathrm{O}_{2}$ concentration of $2 \%$, and the growth was determined by monitoring the optical density at $600 \mathrm{~nm}\left(\mathrm{OD}_{600}\right)$ (Figure 1). Under these conditions, E. meliloti 1021 cells consumed the oxygen present in the atmosphere after incubation for $6 \mathrm{~h}$ and reached anoxic conditions (Figure 1A, insert). Similar oxygen consumption rates were observed for strain 2011 and the napA, nirK, norC and nos $Z$ mutants (data not shown). Confirming the previous results [21], E. meliloti 1021 exhibited a cell density of approximately 1 after $48 \mathrm{~h}$ of incubation in MMN (Figure 1A). A similar growth rate was observed after incubation of the wild-type strain 2011 (data not shown). As shown in Figure 1A, the napA, nirK and nor $C$ mutant strains exhibited growth defects compared with the WT cells, reaching a turbidity of approximately 0.6, 0.7 and 0.35, respectively, after incubation in MMN for $48 \mathrm{~h}$ (Figure 1A). E. meliloti nosZ mutant cells demonstrated similar growth to WT cells (Figure 1A), suggesting that $\operatorname{nos} Z$ was not essential for growth under these conditions. As previously reported for E. meliloti 1021 [21], none of the E. meliloti denitrification mutants were

Table 1 Bacterial strains

\begin{tabular}{|c|c|c|}
\hline Strain & Relevant characteristics & Reference \\
\hline \multicolumn{3}{|l|}{ Ensifer meliloti } \\
\hline 1021 & Wild type; $\mathrm{Sm}^{\mathrm{r}}$ & Meade et al., 1982 [27] \\
\hline 2011 & Wild type & Casse et al., 1979 [28] \\
\hline $2011 \mathrm{mTn} 5$ STM.3.02.F08 & napA::mini-Tn5 $\mathrm{Sm}^{r}, \mathrm{Km}^{r}$ & Pobigaylo et al., 2006 [29] \\
\hline 2011mTn5STM.3.13.D09 & napC::mini-Tn5; Smr ${ }^{r} \mathrm{Km}^{r}$ & Pobigaylo et al., [29] \\
\hline $2011 \mathrm{mTn} 5$ STM.1.13.B08 & nirk:mini-Tn5; Smr $\mathrm{Km}^{r}$ & Pobigaylo et al., [29] \\
\hline SmPI.1021.G1PELR32E8 & norC::PI.G1PELR32E8; Smr $\mathrm{Km}^{r}$ & Becker et al., 2009 [30] \\
\hline $2011 \mathrm{mTn} 5$ STM.5.07.B03 & nosZ::mini-Tn5; Sm ${ }^{r}, \mathrm{Km}^{r}$ & Pobigaylo et al., [29] \\
\hline
\end{tabular}




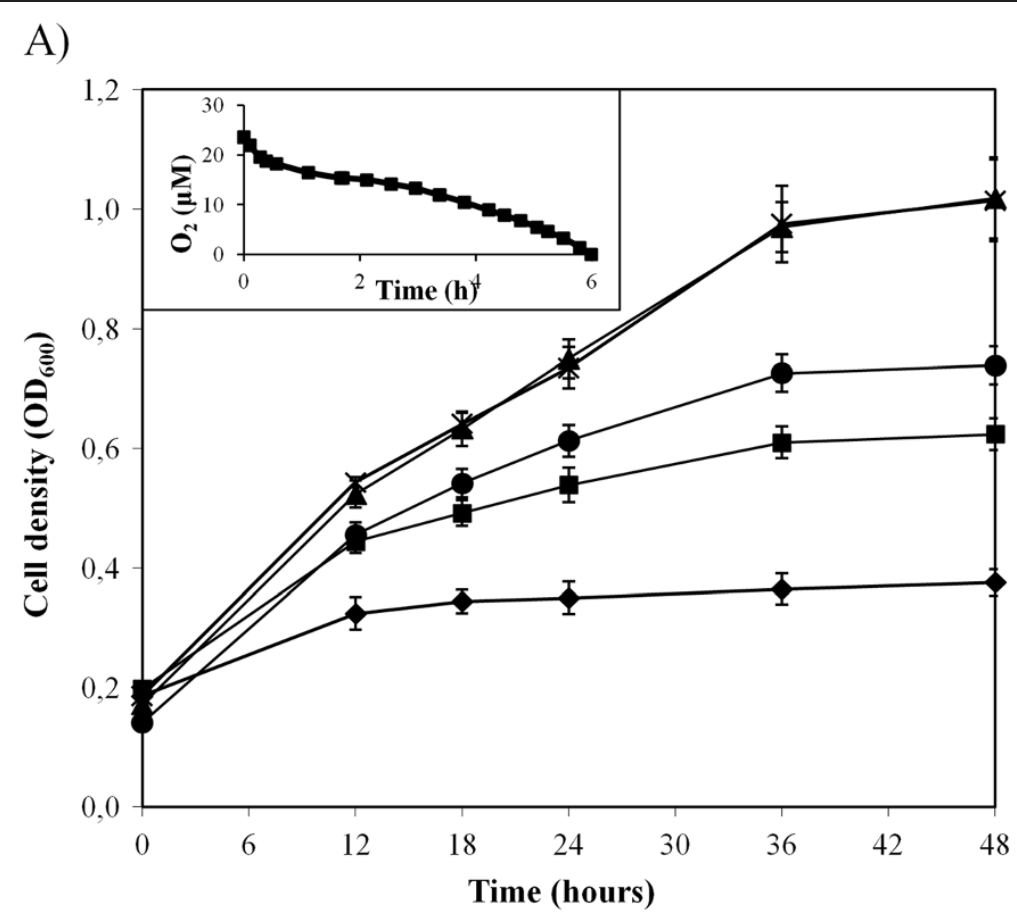

B)

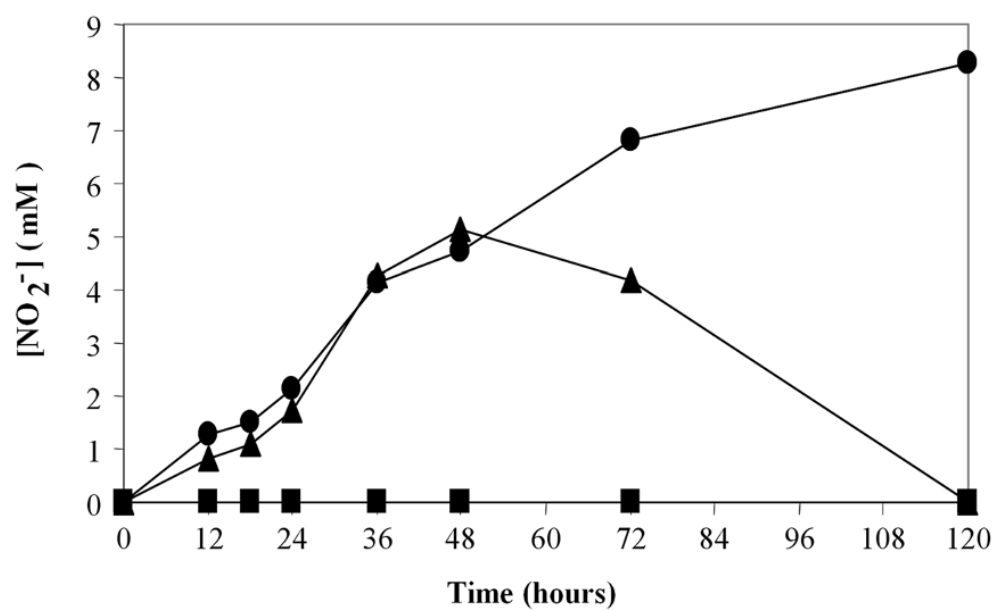

Figure 1 Growth of E. meliloti strains with nitrate. (A) Growth of E. meliloti 1021 ( $\mathbf{\Delta})$ and the napA $(\mathbf{\bullet})$, nirk $(\bullet)$, norC $(\bullet)$ and nosZ $\left(^{*}\right)$ mutant strains in MMN under $2 \%$ initial $\mathrm{O}_{2}$ conditions. The oxygen consumption by the WT cells is also shown (insert). (B) The extracellular nitrite concentrations of E. meliloti $1021(\mathbf{\Delta})$, napA $(\mathbf{\bullet})$ and nirk $(\bullet)$ mutant strains. Representative curves of three independent experiments run in triplicate are shown.

able to grow in MMN when they were subjected to anoxic conditions starting at the beginning of the incubation period (data not shown). As shown in Figure 1B, after incubation in MMN with an initial $\mathrm{O}_{2}$ concentration of $2 \%$, nitrite was not observed in the growth medium of napA. However, in the nirK mutant, the nitrite concentration increased over the course of the incubation period, reaching a final concentration of $8.3 \mathrm{mM}$. The WT strains demonstrated a similar rate of nitrite accumulation during the first $48 \mathrm{~h}$; however, this nitrite was depleted over the subsequent $70 \mathrm{~h}$ of incubation (Figure 1B).

\section{E. meliloti napA, nirK, nor $C$ and nos $Z$ genes encode functional reductases}

The functions of the E. meliloti denitrification genes were also investigated by analysing the activities of the denitrification enzymes in WT and napA, nirK, norC and nos $Z$ mutants incubated under oxygen-limiting conditions. 
Cells of the napA mutant demonstrated an approximately 11 -fold decrease in methyl viologen-dependent nitrate reductase $\left(\mathrm{MV}^{+}-\mathrm{NR}\right)$ activity compared with the WT cells after incubation for $18 \mathrm{~h}$ in MMN with an initial $\mathrm{O}_{2}$ concentration of $2 \%$ (Table 2). As observed for the NR activity in napA cells, the methyl viologen-dependent nitrite reductase $\left(\mathrm{MV}^{+}\right.$-Nir) activity levels in the nirK mutant cells were 10-fold lower than the levels detected in the parental strain when the cells were incubated in MMN with an initial $\mathrm{O}_{2}$ concentration of $2 \%$ (Table 2). As shown in Table 2, the $\mathrm{MV}^{+}$-NR and $\mathrm{MV}^{+}$-Nir activities were detected in WT cells incubated under anoxic conditions from the start of the incubation period. Under these conditions, the NR activity levels in napA cells and the Nir activity levels in nirK cells were undetectable (Table 2).

We also investigated the ability of the E. meliloti nirK and nor $C$ mutants to produce nitric oxide. After incubation for $18 \mathrm{~h}$ with an initial $\mathrm{O}_{2}$ concentration of $2 \%, \mathrm{NO}$ production rates were determined in an NO-electrode chamber after adding nitrite to the reaction mixture. A significant decrease in NO production was observed in the nirK mutant compared with the WT strain $(0.57 \pm$ 0.19 vs. $202 \pm 15 \mathrm{nmol} \mathrm{NO} \cdot \mathrm{mg} \operatorname{protein}^{-1} \cdot \mathrm{min}^{-1}$, respectively), whereas the nor $C$ mutant produced 4.6-fold more NO than the WT cells $(943 \pm 4.52$ vs. $202 \pm 15 \mathrm{nmol}$ $\mathrm{NO} \cdot \mathrm{mg}$ protein $^{-1} \cdot \mathrm{min}^{-1}$, respectively). The high levels of $\mathrm{NO}$ produced by the nor $\mathrm{C}$ mutant are most likely due to its defect in $\mathrm{NO}$ consumption activity. After $18 \mathrm{~h}$ of incubation in $\mathrm{MMN}$ under an initial $\mathrm{O}_{2}$ concentration of $2 \%$, the norC mutant cells demonstrated NO consumption activity that was practically abolished compared with the activity of WT cells (Table 2); the same results were observed when the nor $C$ mutant cells were incubated under initially anoxic conditions.

Figure 2 shows that E. meliloti 1021 is able to produce $\mathrm{N}_{2} \mathrm{O}$ after incubation in MMN under an initial $\mathrm{O}_{2}$ concentration of $2 \%$ and under anoxic conditions. Under both conditions, the nos $\mathrm{Z}$ mutant cells achieved $\mathrm{N}_{2} \mathrm{O}$ accumulation values of approximately 8 - and 2-fold higher than the values produced by WT cells after $18 \mathrm{~h}$ and $36 \mathrm{~h}$ of incubation in MMN, respectively (Figure 2).

\section{Identification of $E$. meliloti NorC}

As previously reported by Torres and colleagues [31], four haem-stained bands of 40, 33, 32 and $27 \mathrm{kDa}$ were detected in E. meliloti 1021 cells grown in minimal media $(\mathrm{MM})$ with an initial $\mathrm{O}_{2}$ concentration of $2 \%$ in the headspace (Figure 3, lane 1). Although the identities of the $40 \mathrm{kDa}$ and $33 \mathrm{kDa}$ proteins are unknown, the $32 \mathrm{kDa}$ and $27 \mathrm{kDa} c$-type cytochromes were identified as the E. meliloti FixP and FixO proteins, respectively, which are subunits of the $c b b_{3}$-type high-affinity cytochrome $c$ oxidase encoded by the fixNOQP operon [31]. The addition of nitrate to the growth medium revealed a haem-stainable band of approximately $16 \mathrm{kDa}$ in the membranes of the WT cells (Figure 3, lane 2). This protein was absent in the norC mutant when it was incubated with a $2 \%$ initial oxygen concentration in MMN (Figure 3, lane 3), which identifies this c-type cytochrome as the NorC component of the E. meliloti 1021 nitric oxide reductase. As shown in Figure 3 (lane 4), membranes from the napC mutant presented a similar band pattern to that of membranes from the WT cells incubated under an initial $\mathrm{O}_{2}$ concentration of $2 \%$ with nitrate (Figure 3, lanes 2 and 4). These results did not permit us to identify the E. meliloti NapC protein, which has a predicted size of $25 \mathrm{kDa}$. In contrast, in other rhizobia species, such as B. japonicum, NapC has been detected via haem-staining analyses and identified as a protein approximately $25 \mathrm{kDa}$ in size [32].

When the cells were subjected to anoxic conditions starting at the beginning of the incubation period, a strong defect in FixP and FixO expression was observed compared with the expression levels detected in cells incubated with an initial $\mathrm{O}_{2}$ concentration of $2 \%$ (Figure 3, lanes 1 and 5). Only proteins approximately 40 and $33 \mathrm{kDa}$ in size could be detected in the anoxically incubated cells. These $40 \mathrm{kDa}$ and $33 \mathrm{kDa}$ proteins were also

Table 2 The methyl viologen-dependent $\left(\mathrm{MV}^{+}\right)$nitrate reductase $\left(\mathrm{MV}^{+}-\mathrm{NR}\right)$, nitrite reductase $\left(\mathrm{MV}^{+}-\mathrm{Nir}\right)$ and nitric oxide reductase (Nor) activities of E. meliloti 1021 (WT) and the napA, nirK, and norC mutant strains incubated in MMN under $2 \%$ initial $\mathrm{O}_{2}$ or anoxic conditions

\begin{tabular}{|c|c|c|c|c|c|c|c|}
\hline \multirow[t]{3}{*}{ Strain } & \multirow[t]{3}{*}{ Genotype } & \multicolumn{6}{|c|}{ Oxygen conditions } \\
\hline & & \multicolumn{3}{|c|}{$2 \% \mathrm{O}_{2}$} & \multicolumn{3}{|c|}{ Anoxia } \\
\hline & & $\mathrm{MV}^{+}-\mathrm{NR}^{\mathrm{a}}$ & $\mathrm{MV}^{+}-\mathrm{NiR}^{\mathrm{b}}$ & Nor $^{c}$ & $\mathrm{MV}^{+}-\mathrm{NR}$ & $\mathrm{MV}^{+}-\mathrm{NiR}$ & Nor \\
\hline 1021 & WT & $210.93(10.33)$ & $32.57(1.42)$ & $563.33(21.81)$ & $62.96(5.70)$ & $10.522(1.465)$ & $335.88(32.12)$ \\
\hline STM.3.02.F08 & napA & $18.86(3.79)$ & - & - & n.d. & - & - \\
\hline STM.1.13.B08 & nirk & - & $3.34(0.26)$ & $528.26(20.86)$ & - & n.d. & $308.19(23.18)$ \\
\hline G1PELR32E8 & norc & - & - & $1.11(0.01)$ & - & - & $2.84(0.78)$ \\
\hline
\end{tabular}

${ }^{\mathrm{a}} \mathrm{MV}^{+}-\mathrm{NR}$ and ${ }^{\mathrm{b}} \mathrm{MV}^{+}$-Nir activities are expressed as $\mathrm{nmol} \mathrm{NO}{ }_{2}^{-}$produced or consumed $\cdot \mathrm{mg}$ protein ${ }^{-1} \cdot \mathrm{min}^{-1}$. Nor activity is expressed as $\mathrm{nmol} \mathrm{NO}$ consumed $\cdot \mathrm{mg}^{-}$ protein ${ }^{-1} \cdot \min ^{-1}$. All of the activities were determined after incubation for $18 \mathrm{~h}$. The data are expressed as the means with the standard error in parentheses from at least two different cultures assayed in triplicate. -, not determined; n.d., not detectable. 


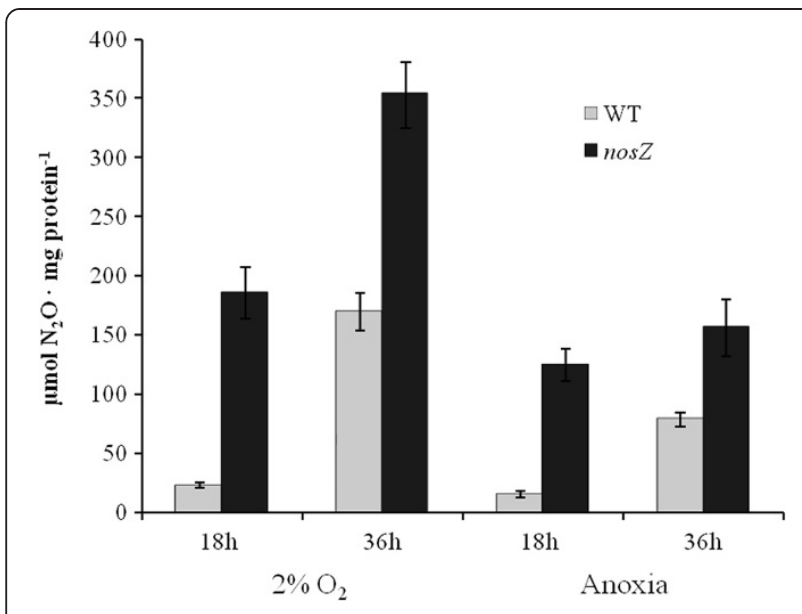

Figure $2 \mathrm{~N}_{2} \mathrm{O}$ accumulation in E. meliloti 1021 (WT) and the nos $Z$ mutant incubated in MMN under $2 \%$ initial $\mathrm{O}_{2}$ or anoxic conditions. $\mathrm{N}_{2} \mathrm{O}$ was measured in the headspace of the cultures after 18 and $36 \mathrm{~h}$ of incubation. The data represent the means with the standard deviations from at least two different cultures assayed in triplicate.

present in cells grown under oxic conditions [31]. These proteins might remain in the membranes of cells that are grown aerobically prior to the anoxic incubation period. As shown in Figure 3 (lanes 2 and 6), nitratedependent NorC expression decreased under anoxic conditions compared with cells incubated with an initial $\mathrm{O}_{2}$ concentration of $2 \%$. As observed for NorC, the expression of FixP and FixO was weak in the membranes from the anoxically incubated cells in the presence of nitrate (Figure 4, lanes 2 and 6).

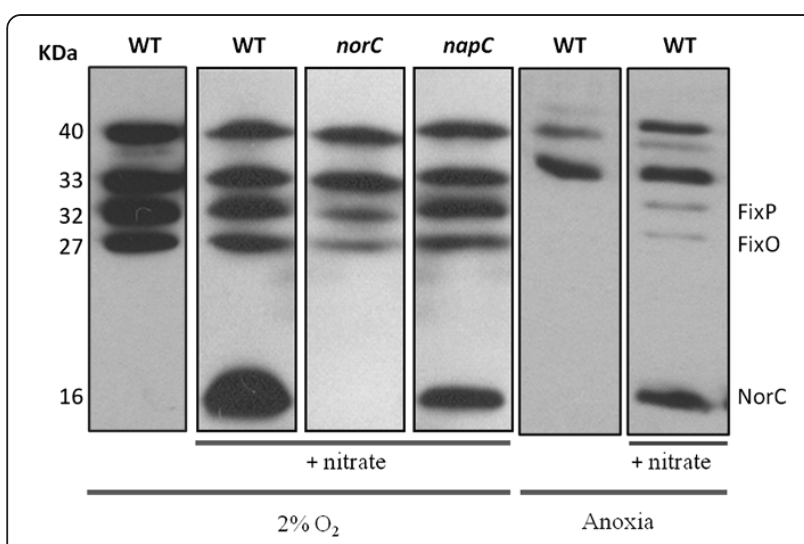

Figure 3 Haem-stained proteins of membranes prepared from E. meliloti 1021 (WT) and the norC and napC mutants incubated

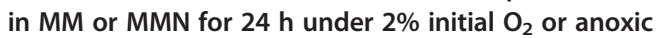
conditions. Each lane contains $25 \mathrm{\mu g}$ of membrane proteins. Haem-stained c-type cytochromes identified previously (FixP and FixO) and in this work (NorC) are specified in the right margin. Apparent protein molecular masses $(\mathrm{kDa})$ are shown in the left margin.

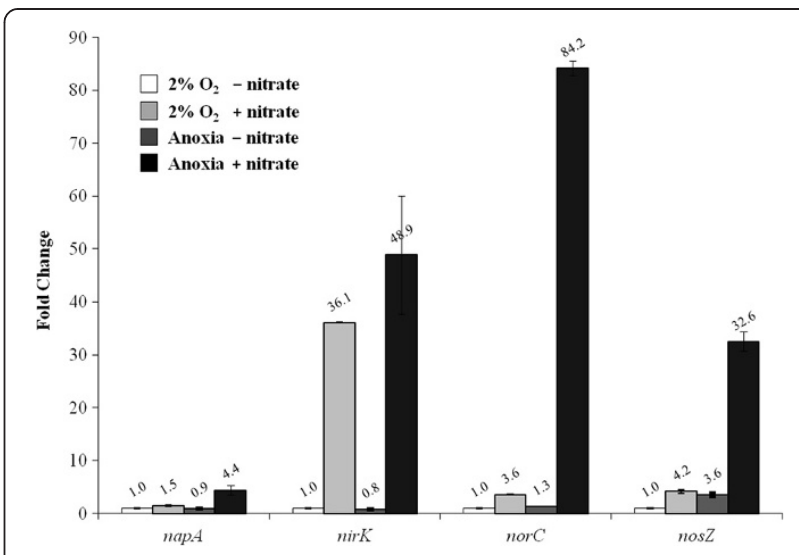

Figure 4 Expression of E. meliloti 1021 napA, nirk, norC and nos $Z$ denitrification genes in cells incubated for $12 \mathrm{~h}$ in $\mathrm{MM}$ or MMN under an initial oxygen concentration of $2 \%$ or under anoxic conditions. The transcription levels were quantified using qRT-PCR with total RNA samples as the templates. The data were analysed using the standard curve method (nirk data were analysed with the comparative $C_{T}$ method), and the expression levels were normalised against the E. meliloti smc00128 gene as an internal standard. The values expressed relative to the values of cells incubated under $2 \%$ initial $\mathrm{O}_{2}$ in the absence of nitrate are the means and standard deviations of three independent experiments run in triplicate.

\section{Expression of E. meliloti denitrification genes}

We analysed the expression of the E. meliloti napA, nirK, nor $C$ and nos $Z$ genes using qRT-PCR analyses. With the exception of nirK expression, which was induced 36-fold by nitrate, the presence of nitrate in the growth medium of cells incubated under an initial $\mathrm{O}_{2}$ concentration of $2 \%$ provoked the induction of napA, norC and nos Z expression by 1.5-, 3.6- and 4.2-fold, respectively, compared with the expression observed in the absence of nitrate (Figure 4). When the cells were incubated anoxically from the beginning of culture, the napA, nirK, norC and nos $Z$ genes were induced approximately 4-, 48-, 84- and 32-fold by nitrate compared with the expression levels observed after a $12 \mathrm{~h}$ incubation in $\mathrm{MM}$ at an initial $\mathrm{O}_{2}$ concentration of $2 \%$ (Figure 4 ). These results indicate that the maximal expression of the E. meliloti napA, nirK, norC and nos $Z$ denitrification genes occurs when the cells are initially incubated anoxically and when nitrate is present in the growth medium.

\section{Discussion}

E. meliloti has been considered a partial denitrifier because of its traditionally reported inability to use nitrate as an electron acceptor for ATP generation and growth under anoxic conditions [18,33]. Recent results from our group confirmed the inability of E. meliloti to grow via nitrate respiration when cells were initially incubated under anoxic conditions [21]; however, E. meliloti 1021 was able to use nitrate as a respiratory substrate when 
cells were initially incubated with $2 \% \mathrm{O}_{2}$ in the headspace [21]. Under these conditions, $\mathrm{O}_{2}$ was consumed after $6 \mathrm{~h}$ of incubation, as we demonstrated in the present manuscript. In this work, we demonstrated that E. meliloti nap genes are involved in E. meliloti nitratedependent growth and that nitrite derived from nitrate reduction is produced by Nap. The low levels of NR activity observed in the napA mutant explain the growth defect and the inability of this strain to produce nitrite in cells incubated in MMN with $2 \%$ initial $\mathrm{O}_{2}$. The majority of the most well-characterised denitrifying bacteria use the membrane-bound nitrate reductase (Nar) to catalyse the first step of denitrification. In contrast to Nar, which has a respiratory function, Nap systems demonstrate a range of physiological functions, including the disposal of reducing equivalents during aerobic growth on reduced carbon substrates or anaerobic nitrate respiration [2-6]. Our results support the proposed role of Nap in nitrate respiration. Some rhizobial species, such as Pseudomonas sp. G179 (Rhizobium galegae) and Bradyrhizobium japonicum, could express nap genes under anaerobic conditions, and the disruption of these genes is lethal for growth under denitrifying conditions [32,34].

Whereas the deletion of nos $Z$ did not have a significant effect on the ability of $E$. meliloti to respire nitrate and increase growth yield, the nirK and nor $C$ mutants exhibited clear defects in nitrate-dependent growth, most likely because of the toxicity of the intermediates nitrite and nitric oxide, respectively. Nitrite or NO were accumulated by the nirK and nor C mutants, respectively, because of the strong defects in Nir and Nor activities observed in these mutants compared with WT levels. Similar phenotypes for nirK and norC mutants were reported for B. japonicum [35,36] and Rhizobium etli [37]. The increased levels of $\mathrm{N}_{2} \mathrm{O}$ accumulated by the $n o s Z$ mutant relative to the WT cells indicated that this gene is involved in nitrous oxide reduction in E. meliloti. Similar observations were noted with a $B$. japonicum nos $Z$ mutant [38]. In addition to demonstrate the involvement of the E. meliloti napA, nirK, nor $C$ and nos $Z$ genes in nitrate, nitrite, nitric oxide and nitrous oxide reduction, respectively, we have identified the NorC subunit of nitric oxide reductase as a cytochrome $\mathrm{c}$ that is approximately $16 \mathrm{kDa}$ in size.

Growth experiments in this study and in previous studies [21] clearly demonstrated that $E$. meliloti utilises nitratedependent growth when transitioning to anoxic conditions occurs when cells are incubated under an initial $\mathrm{O}_{2}$ concentration of $2 \%$; however, nitrate-dependent growth does not occur when cells are subjected to anoxic conditions starting at the beginning of the incubation period. To understand the differential responses of E. meliloti denitrification capability to these different anoxically induced conditions, we investigated the ability of E. meliloti to express the denitrification genes in cells incubated under $2 \%$ initial $\mathrm{O}_{2}$ compared with cells initially subjected to anoxic conditions. Despite the inability of E. meliloti to grow, we demonstrated that the napA, nirK, nor $C$ and $n o s Z$ denitrification genes were fully induced in cells initially subjected to anoxia and in the presence of nitrate. Furthermore, denitrification enzymes are active in cells initially incubated under anoxic conditions; we were able to detect significant $\mathrm{MV}^{+}-\mathrm{NR}, \mathrm{MV}^{+}-\mathrm{NiR}$ and Nor activity levels and $\mathrm{N}_{2} \mathrm{O}$ production under these conditions. In contrast, the protein levels corresponding to NorC and the FixP and FixO components of the high affinity $c b b_{3}$ oxidase were very weak after incubation of the cells under anoxic conditions starting at the beginning of the incubation period. The latter observations might explain the limited nitrate-dependent growth capacity of E. meliloti when anoxic conditions are induced starting at the beginning of the growth period. Under these conditions, cells would be trapped, without energy, and they would be unable to produce the proteins required to cope with the oxygen-limiting conditions, most likely because of the lack of energy. Supporting this hypothesis, it was reported in Pseudomonas sp. G59 that the formation of nitrate reductase and nitrous oxide reductase did not occur under aerobic or anaerobic conditions; however, nitrate reductase and nitrous oxide reductase were produced under microaerobic incubation [39]. The latter study suggests that dependence on microaerobiosis for the formation of these reductases was attributable to an inability to produce energy anaerobically until these anaerobic respiratory enzymes formed [39]. Recent studies have shown that the soil bacterium Agrobacterium tumefaciens is unable to maintain balanced expression of denitrification genes if oxygen depletion occurs too quickly $[40,41]$. Similarly, the soil bacterium $P$. denitrificans appears unable to effectively switch from oxic to anoxic respiration, leaving a large fraction of the cell population in anoxia without a chance to express the denitrification proteome [41]. As suggested by Nadeem and co-workers [42], "microaerobic" denitrification is an essential trait for securing an efficient transition to anaerobic denitrification. Considering that B. japonicum, which is able to grow under anoxic nitrate-respiring conditions, is a slow-growth bacterium and E. meliloti is a fast-growth bacterium, the transition from oxic to anoxic metabolism might be different in these species. Supporting this suggestion, we observed that B. japonicum cells are able to express the FixO and FixP subunits of the $c b b_{3}$ oxidase under anoxic conditions (E. Bueno, personal communication). However, as shown in this work, E. meliloti does not express the FixO and FixP proteins under anoxic conditions. A lack of the energy necessary for protein synthesis might contribute to the inability of $E$. meliloti to grow via nitrate respiration when cells are initially incubated anoxically. 


\section{Conclusion}

The potential impact of denitrification by plant endosymbiotic bacteria on the emission of the greenhouse gas $\mathrm{N}_{2} \mathrm{O}$ has been poorly investigated. The results of this work demonstrate the involvement of the napA, nirK, nor $C$ and nos $Z$ genes in the previously reported ability of $E$. meliloti to grow via nitrate respiration when cells are subjected initially to $2 \% \mathrm{O}_{2}$. Furthermore, the roles of the reductases encoded by napA, nirK, norC and nos $Z$ in nitrite, nitric oxide, $\mathrm{N}_{2} \mathrm{O}$ production and $\mathrm{N}_{2} \mathrm{O}$ reduction, respectively, were demonstrated. Thus, our results contribute to the investigation of the unexplored genetic basis for denitrification in the alfalfa endosymbiont E. meliloti. This knowledge will be instrumental in the development of agricultural strategies and management practices for mitigating the release of $\mathrm{N}_{2} \mathrm{O}$ from legume crops.

\section{Methods}

\section{Bacterial strains and growth conditions}

The bacterial strains used in this study are listed in Table 1. E. meliloti strains were routinely grown aerobically at $30^{\circ} \mathrm{C}$ in tryptone yeast (TY) complete medium [43]. These cultures were then used as the inocula for subsequent incubation experiments, which were performed in minimal medium (MM) [44] or in MM medium supplemented with $10 \mathrm{mM} \mathrm{KNO}_{3}$ (MMN); the cells were subjected to two experimental oxygen-limiting conditions. In the first set of experiments, $17-\mathrm{ml}$ serum tubes or $500-\mathrm{ml}$ flasks containing 5 or $200 \mathrm{ml}$ medium, respectively, were sealed with rubber septa, and the headspace atmospheres were replaced with a gas mixture ( $2 \%$ oxygen, $98 \%$ argon) at the starting point of the incubation. In the second experiment, the cells were incubated in completely filled $200-\mathrm{ml}$ bottles or $17-\mathrm{ml}$ tubes without added oxygen; these conditions are referred to throughout the manuscript as "anoxic conditions". Antibiotics were added to the cultures at the following concentrations $\left(\mu \mathrm{g} \cdot \mathrm{ml}^{-1}\right)$ : streptomycin, 200; and kanamycin, 200.

\section{Headspace $\mathrm{O}_{2}$ measurements}

After inoculation at an $\mathrm{OD}_{600}$ of $0.2,1 \mathrm{ml}$ of each culture was placed in a 3-ml thermostatted and magnetically stirred reaction chamber with an $\mathrm{O}_{2}$ electrode (Hansatech, Norkfolk, England). The headspace atmosphere in the chamber was replaced with a gas mixture ( $2 \%$ oxygen, $98 \%$ argon) at the starting point of the incubation. The kinetics of oxygen depletion in the chamber were monitored.

\section{Determination of nitrate reductase and nitrite reductase activity}

E. meliloti cells were incubated (initial $\mathrm{OD}_{600}$ of approximately $0.15-0.2)$ under $2 \%$ initial oxygen or under anoxic conditions for $18 \mathrm{~h}$ in MMN medium. The cells were harvested by centrifugation at $8000 \mathrm{~g}$ for $10 \mathrm{~min}$ at $4^{\circ} \mathrm{C}$, washed with $50 \mathrm{mM}$ Tris/ $\mathrm{HCl}$ buffer $(\mathrm{pH}$ 7.5) until no nitrite was detected and then resuspended in $0.5 \mathrm{ml}$ of the same buffer. The methyl viologen-dependent nitrate reductase $\left(\mathrm{MV}^{+}-\mathrm{NR}\right)$ activity was analysed essentially as described by Delgado and colleagues (2003) [32]. To determine the methyl viologen-dependent nitrite reductase $\left(\mathrm{MV}^{+}-\mathrm{Nir}\right)$ activity, the reaction mixture contained $50 \mathrm{mM}$ Tris/HCl buffer (pH 7.5), $200 \mu \mathrm{M} \mathrm{NaNO}$, $400 \mu \mathrm{M}$ methyl viologen (MV) and $100 \mu \mathrm{l}$ of cell suspension (0.02-0.04 $\mathrm{mg}$ of protein). The reaction was started by the addition of $50 \mu \mathrm{l}$ of freshly prepared sodium dithionite solution $\left(30 \mathrm{mg} \cdot \mathrm{ml}^{-1}\right.$ in $300 \mathrm{mM}$ $\mathrm{NaHCO}_{3}$ ). After incubation for $20 \mathrm{~min}$ at $30^{\circ} \mathrm{C}$, the reaction was stopped by vigorous shaking until the samples lost their blue colour.

\section{Haem-staining analysis}

E. meliloti cells grown aerobically in $150 \mathrm{ml}$ of TY medium were harvested by centrifugation at $8000 \mathrm{~g}$ for $5 \mathrm{~min}$, washed twice with MM, resuspended in $200 \mathrm{ml}$ of MM or $\mathrm{MMN}$ at an $\mathrm{OD}_{600}$ of $0.15-0.2$ and incubated under $2 \%$ initial $\mathrm{O}_{2}$ or anoxic (filled bottles) conditions for $24 \mathrm{~h}$. The cell pellets were resuspended in $3 \mathrm{ml}$ of $50 \mathrm{mM}$ potassium phosphate buffer ( $\mathrm{pH}$ 7) containing $100 \mu \mathrm{M}$ 4-(2aminoethyl) benzene-sulfonyl fluoride hydrochloride (ABSF), RNAse $\left(20 \mu \mathrm{g} \cdot \mathrm{ml}^{-1}\right)$ and DNAse I $\left(20 \mu \mathrm{g} \cdot \mathrm{ml}^{-1}\right)$. The cells were disrupted using a French pressure cell at a constant pressure of approximately 1000 psi (SLM Aminco, Jessup, MD, USA). The cell extract was centrifuged at 10,000 $g$ for $20 \mathrm{~min}$ to remove the unbroken cells, and the supernatant was centrifuged at $140,000 \mathrm{~g}$ for $1 \mathrm{~h}$. The membrane pellet was resuspended in $100 \mu$ of the same buffer. The membrane protein aliquots were diluted in sample buffer [124 mM Tris-HCl, pH 7.0, 20\% glycerol, $4.6 \%$ sodium dodecyl sulphate (SDS) and $50 \mathrm{mM} 2$ mercaptoethanol] and incubated at room temperature for $10 \mathrm{~min}$. The membrane proteins were separated at $4^{\circ} \mathrm{C}$ using $12 \%$ SDS-polyacrylamide gel electrophoresis, transferred to a nitrocellulose membrane and stained for haem-dependent peroxidase activity, as described previously [45], using the SuperSignal chemiluminescence detection kit (Pierce, Thermo Fisher Scientific, IL, USA).

\section{Analytical methods}

The nitrite concentration was estimated after diazotisation by adding the sulphanilamide/naphthylethylene diamine dihydrochloride reagent [46]. The protein concentration was estimated using the Bradford method (Bio-Rad Laboratories, Richmond, CA) with a standard curve constructed with varying bovine serum albumin concentrations. 


\section{Nitric oxide determination}

E. meliloti cells were incubated at an $\mathrm{OD}_{600}$ of $0.15-0.2$ in MMN under $2 \%$ initial $\mathrm{O}_{2}$ or anoxic conditions, harvested and washed similar to the NR or Nir activity assays. Nitric oxide was measured amperometrically with a 2-mm ISONOP electrode APOLO $4000^{\circ}$ (World Precision Inst., Sarasota, FL, USA) in a 3-ml thermostatted and magnetically stirred reaction chamber [47]. The membrane-covered electrode was situated at the bottom of the chamber above the stirrer, and the reactants were injected using a Hamilton syringe through a port in the glass stopper. To determine the net production of NO, the 3-ml cuvette was filled with $1.410 \mathrm{ml}$ of $25 \mathrm{mM}$ phosphate buffer ( $\mathrm{pH} 7.4), 250 \mu \mathrm{l}$ (0.1-0.2 mg protein) of a cellular solution, $100 \mu \mathrm{l}$ of an enzymatic mix containing glucose oxidase (Aspergillus niger) ( 80 units $/ 2 \mathrm{ml})$ and catalase (bovine liver) (500 units/2 ml), $90 \mu \mathrm{l}$ of $1 \mathrm{M}$ sodium succinate and $100 \mu \mathrm{l}$ of $320 \mathrm{mM}$ glucose. When oxygen was consumed and a steady base line was observed, $50 \mu \mathrm{l}$ of $1 \mathrm{M} \mathrm{NaNO}_{2}$ was added to the cuvette to begin the reaction. Each assay was continued until NO was detected. To determine the NO consumption rates, the electrode chamber was filled with $1.655 \mathrm{ml}$ of $25 \mathrm{mM}$ phosphate buffer ( $\mathrm{pH} 7.4), 5 \mu \mathrm{l}$ (0.02-0.04 mg protein) of a cellular solution, $100 \mu \mathrm{l}$ of an enzymatic mix containing glucose oxidase (Aspergillus niger) ( 80 units $/ 2 \mathrm{ml}$ ) and catalase (bovine liver) (500 units/2 ml), $90 \mu \mathrm{l}$ of $1 \mathrm{M}$ sodium succinate and $100 \mu \mathrm{l}$ of $320 \mathrm{mM}$ glucose. Once a steady base line was observed, $50 \mu \mathrm{l}$ of a saturated NO solution $\left(1.91 \mathrm{mM}\right.$ at $\left.20^{\circ} \mathrm{C}\right)$ was added to the cuvette to start the reaction. Each assay was continued until NO detection dropped to zero (when all of the NO was consumed).

\section{Nitrous oxide determination}

E. meliloti cells were incubated in MMN with an initial $\mathrm{O}_{2}$ concentration of $2 \%$ in the headspace or anoxically. After 18 or $36 \mathrm{~h}$ of incubation, $500-\mu \mathrm{l}$ gaseous aliquots were taken from the culture headspaces to determine the $\mathrm{N}_{2} \mathrm{O}$ level. In anoxic cultures (filled tubes), headspace was created by transferring $10 \mathrm{ml}$ of liquid culture into a $20-\mathrm{ml}$ headspace vial $\left(\right.$ Supelco $\left.^{\circ}\right)$. Gas-liquid phase equilibration was performed by incubating the vials for $2 \mathrm{~h}$ at $30^{\circ} \mathrm{C}$ and at $185 \mathrm{rpm}$. To stop cell growth, $200 \mu \mathrm{l}$ of $1 \mathrm{mg} \cdot \mathrm{ml}^{-1} \mathrm{HgCl}_{2}$ was added to each vial. The $\mathrm{N}_{2} \mathrm{O}$ production in liquid cultures was corrected using the dissolved $\mathrm{N}_{2} \mathrm{O}$ Bunsen solubility coefficient $(47.2 \%$ at $30^{\circ} \mathrm{C}$ ). Then, $\mathrm{N}_{2} \mathrm{O}$ was measured with a gas chromatograph type HP 4890D equipped with an electron capture detector (ECD). The column was packed with Porapak Q $80 / 100 \mathrm{MESH}\left(6 \mathrm{ft}\right.$ ), and the carrier gas was $\mathrm{N}_{2}$ at a flow rate of $23 \mathrm{ml} / \mathrm{min}$. The injector, column and detector temperatures were 125,60 and $375^{\circ} \mathrm{C}$, respectively. The $\mathrm{N}_{2} \mathrm{O}$ peaks were integrated using GC ChemStation
Software (Agilent Technologies ${ }^{\odot}$ 1990-2003). The samples were injected manually through a Hamilton ${ }^{\circ}$ Gastight syringe. The concentrations of $\mathrm{N}_{2} \mathrm{O}$ in each sample were calculated from pure nitrous oxide standards (Air Liquid, France).

\section{Quantitative real-time PCR analysis}

For immediate stabilisation of the bacterial RNA, the RNAprotect Bacteria Reagent (Qiagen Valencia, CA, USA) was added directly to cells incubated for $12 \mathrm{~h}$ in MM or MMN with an initial headspace $\mathrm{O}_{2}$ concentration of $2 \%$ or anoxically. Bacterial lysis was performed by resuspension and incubation of the cell pellet in $1 \mathrm{mg} / \mathrm{ml}$ lysozyme from chicken egg whites (Sigma-Aldrich) in Tris-EDTA buffer, $\mathrm{pH}$ 8.0. The total RNA was isolated using the RNeasy Mini kit (Qiagen). The isolated RNA was subjected to DNase (Qiagen) treatment. The RNA was quantified using a NanoDrop 1000 Spectrophotometer (Thermo Scientific, USA), and intactness was verified by the visual inspection of rRNA bands in electrophoretically separated total RNA [48]. Reverse transcription reactions were performed with $0.8 \mu \mathrm{g}$ of total RNA per reaction using the First Strand cDNA Synthesis kit for RT-PCR (Roche) with random hexamers. The cDNA synthesis reaction mixture was diluted 50 times with distilled water before use in real-time PCR analysis.

The primers for the PCR reactions were designed using Primer Express v3.0 software (PE Applied Biosystems, Foster City, CA, USA) to have a melting temperature of approximately $57^{\circ} \mathrm{C}$ to $62^{\circ} \mathrm{C}$ and to produce a PCR product of approximately 50 to $100 \mathrm{bp}$. The primer sequences were as follows: napA (forward, 5'-CCGGCTATCGTGG CAAGA-3'; reverse, 5' -CGGGAAGCTGTCGACATTG3'); nirK (forward, 5' -CCGCGCGACGCAAA-3'; reverse, 5'-TCGAGCGTATCGGCATAGG-3'); norC (forward, 5' AGCTCACAGAGCAGGAACTGAAC-3'; reverse, 5' -TG ATGCGGCTCGTCCATT-3'); and nos $Z$ (forward, $5^{\prime}$-CG AGGATCTCACGCATGGAT-3'; reverse, 5'-GCGGTGC AACCTCCATGT-3'). sMC00128 was used as an internal standard [49,50] (forward, 5' -ACGAGATCGAGATCG CCATT-3'; reverse, $5^{\prime}$-CGAACGAGGTCTTCAGCAT GA-3').

Each PCR reaction contained $7.5 \mu \mathrm{l}$ of SYBR Green PCR master mix (PE Applied Biosystems), $5 \mu$ of cDNA and various final concentrations of each primer depending on the studied gene. This concentration was $0.2 \mu \mathrm{M}$ for norC and $s M C 00128$ and $0.4 \mu \mathrm{M}$ for napA, nosZ and nirK. The final volume of the PCR reactions was $15 \mu$. The real-time PCR reactions were performed on a 7300 Real Time PCR System (PE Applied Biosystems). The initial denaturing time of $10 \mathrm{~min}$ was followed by 40 PCR cycles consisting of $95^{\circ} \mathrm{C}$ for $15 \mathrm{~s}$ and $60^{\circ} \mathrm{C}$ for $60 \mathrm{~s}$. A melting curve was run after the PCR cycles. During realtime PCR, the efficiency of nirK gene amplification was 
approximately equal to that of the housekeeping (internal standard) gene; in this case, the comparative $\mathrm{C}_{\mathrm{T}}$ method (also called $\Delta \Delta \mathrm{C}_{\mathrm{T}}$ method) was applied for relative quantification. For the other genes, the amplification efficiencies were different from that of the housekeeping gene; the comparative $\mathrm{C}_{\mathrm{T}}$ method could not be applied, and it was necessary to use the standard curve method. The data were analysed using the 7300 System Software (PE Applied Biosystems). The gene expression values under different conditions were expressed relative to the values of cells incubated under an initial $\mathrm{O}_{2}$ concentration of $2 \%$ in the absence of nitrate.

\section{Competing interests}

The authors declare that they have no competing interests.

\section{Authors' contributions}

MJT and MJD conceived of the study. MJT and MIR carried out the phenotypic analyses of the E. meliloti denitrification mutants. TC and JJP participated in the gene expression experiments. MJD and EJB supported the research. MJT and MJD wrote the manuscript. EJB coordinated and critically revised the manuscript. All of the authors read and approved the manuscript.

\section{Acknowledgments}

This work was supported by a Fondo Europeo de Desarrollo Regional (FEDER)-Co-financed grant (AGL2010-18607) and grant AGL2009-10371 from the Ministerio de Economía y Competitividad (Spain). Grant S2009/AMB-1511 from the Comunidad de Madrid and support from the Junta de Andalucía to Group BIO-275 are also acknowledged. We thank G. Tortosa for technical support and A. Becker for providing the E. meliloti mutants. MJT was supported by a fellowship from the Consejo Superior de Investigaciones Cientificas I3P Programme.

\section{Author details}

'Estación Experimental del Zaidin, Consejo Superior de Investigaciones Científicas (CSIC), P.O. Box 419, 18080 Granada, Spain. ${ }^{2}$ Instituto de Ciencias Agrarias, Consejo Superior de Investigaciones Científicas (CSIC), Serrano 115-bis, 28006 Madrid, Spain.

Received: 19 February 2014 Accepted: 28 May 2014

Published: 2 June 2014

\section{References}

1. Bates BC, Kundzewicz ZW, Wu S, Palutikof JP: Climate Change and Water. Technical Paper of the Intergovernmental Panel on Climate Change. Geneva, Switzerland: IPCC Secretariat; 2008:210.

2. Gonzalez PJ, Correia C, Moura I, Brondino CD, Moura JJ: Bacterial nitrate reductases: molecular and biological aspects of nitrate reduction. $J$ Inorg Biochem 2006, 100(5-6):1015-1023.

3. Kraft B, Strous M, Tegetmeyer HE: Microbial nitrate respiration-genes, enzymes and environmental distribution. J Biotechnol 2011, 155(1):104-117.

4. Richardson DJ: Redox complexes of the nitrogen cycle. In Nitrogen Cycling in Bacteria. Edited by Moir JWB. Norkfolk, UK: Caister Academic Press; 2011:23-39.

5. Richardson DJ, Berks BC, Russell DA, Spiro S, Taylor CJ: Functional, biochemical and genetic diversity of prokaryotic nitrate reductases. Cell Mol Life Sci 2001, 58(2):165-178.

6. Richardson DJ, van Spanning RJ, Ferguson SJ: The prokaryotic nitrate reductases. In Biology of the Nitrogen Cycle. Edited by Bothe H, Ferguson SJ, Newton WE. The Nerthelands: Elservier; 2007:21-35.

7. Rinaldo S, Arcovito A, Giardina G, Castiglione N, Brunori M, Cutruzzola F: New insights into the activity of Pseudomonas aeruginosa $\mathrm{cd} 1$ nitrite reductase. Biochem Soc Trans 2008, 36(Pt 6):1155-1159.
8. Rinaldo S, Cutruzzola F: Nitrite reductases in denitrification. In Biology of the Nitrogen Cycle. Edited by Bothe H, Ferguson SJ, Newton WE. The Netherlands: Elservier; 2007:37-56.

9. van Spanning RJ, Delgado MJ, Richardson DJ: The nitrogen cycle: denitrification and its relationship to $\mathrm{N}_{2}$ fixation. In Nitrogen Fixation in Agriculture, Forestry, Ecology and the Environment. Edited by Werner D, Newton WE. Netherlands: Springer; 2005:277-342.

10. van Spanning RJ, Richardson DJ, Ferguson SJ: Introduction to the biochemistry and molecular biology of denitrification. In Biology of the Nitrogen Cycle.3-20. Edited by Bothe H, Ferguson SJ, Newton WE. Amsterdam: Elsevier Science; 2007.

11. van Spanning RJ: Structure, function, regulation and evolution of the nitrite and nitrous oxide reductase: denitrification enzymes with a b-propeller fold. In Nitrogen Cycling in Bacteria. Edited by Moir JWB. Norkfolk, UK: Caister Academic Press; 2011:135-161.

12. de Vries R, Suharti R, Pouvreau LAM: Nitric oxide reductase: structural variations and catalytic mechanism. In Biology of the Nitrogen Cycle. Edited by Bothe H, Ferguson SJ, Newton WE. The Netherlands: Elsevier; 2007:57-66.

13. Zumft WG, Kroneck PM: Respiratory transformation of nitrous oxide $\left(\mathrm{N}_{2} \mathrm{O}\right)$ to dinitrogen by Bacteria and Archaea. Adv Microb Physiol 2007, 52:107-227.

14. Thomson AJ, Giannopoulos G, Pretty J, Baggs EM, Richardson DJ: Biological sources and sinks of nitrous oxide and strategies to mitigate emissions. Philos Trans R Soc Lond B Biol Sci 2012, 367(1593):1157-1168

15. Hartsock A, Shapleigh JP: Identification, functional studies, and genomic comparisons of new members of the NnrR regulon in Rhodobacter sphaeroides. J Bacteriol 2010, 192(4):903-911.

16. Baggs EM, Rees RM, Smith KA, Vinten AJA: Nitrous oxide emission from soils after incorporating crop residues. Soil Use Manag 2000, 16(2):82-87.

17. Bedmar EJ, Robles EF, Delgado MJ: The complete denitrification pathway of the symbiotic, nitrogen-fixing bacterium Bradyrhizobium japonicum. Biochem Soc Trans 2005, 33(Pt 1):141-144.

18. Garcia-Plazaola Jl, Becerril JM, Arrese-Igor C, Hernandez A, Gonzalez-Murua C, Aparicio-Tejo PM: Denitrifying ability of thirteen Rhizobium meliloti strains. Plant Soil 1993, 149:43-50

19. Sánchez C, Bedmar EJ Delgado MJ: Denitrification in Legume-associated endosymbiotic Bacteria. In Nitrogen cycling in Bacteria. Edited by Moir JWB. Norfolk, UK: Caister Academic Press; 2011:197-210.

20. Delgado MJ, Casella S, Bedmar EJ: Denitrification in rhizobia-legume symbiosis. In Biology of the Nitrogen Cycle. Edited by Bothe H, Ferguson SJ, Newton WE. Amsterdam: Elsevier Science; 2007:83-93.

21. Torres MJ, Rubia MI, Bedmar EJ, Delgado MJ: Denitrification in Sinorhizobium meliloti. Biochem Soc Trans 2011, 39(6):1886-1889.

22. Barnett MJ, Fisher RF, Jones T, Komp C, Abola AP, Barloy-Hubler F, Bowser L, Capela D, Galibert F, Gouzy J, Gurjal M, Hong A, Huizar L, Hyman RW, Kahn D, Kahn ML, Kalman S, Keating DH, Palm C, Peck MC, Surzycki R, Wells DH, Yeh KC, Davis RW, Federspiel NA, Long SR: Nucleotide sequence and predicted functions of the entire Sinorhizobium meliloti pSymA megaplasmid. Proc Natl Acad Sci U S A 2001, 98(17):9883-9888.

23. Becker A, Berges H, Krol E, Bruand C, Ruberg S, Capela D, Lauber E, Meilhoc E, Ampe F, de Bruijn FJ, Fourment J, Francez-Charlot A, Kahn D, Kuster H, Liebe C, Puhler A, Weidner S, Batut J: Global changes in gene expression in Sinorhizobium meliloti 1021 under microoxic and symbiotic conditions. Mol Plant Microbe Interact 2004, 17(3):292-303.

24. Bobik C, Meilhoc E, Batut J: FixJ: a major regulator of the oxygen limitation response and late symbiotic functions of Sinorhizobium meliloti. J Bacteriol 2006, 188(13):4890-4902.

25. Meilhoc E, Cam Y, Skapski A, Bruand C: The response to nitric oxide of the nitrogen-fixing symbiont Sinorhizobium meliloti. Mol Plant Microbe Interact 2010, 23(6):748-759.

26. Horchani F, Prevot M, Boscari A, Evangelisti E, Meilhoc E, Bruand C, Raymond P, Boncompagni E, Aschi-Smiti S, Puppo A, Brouquisse R: Both plant and bacterial nitrate reductases contribute to nitric oxide production in Medicago truncatula nitrogen-fixing nodules. Plant Physiol 2011, 155(2):1023-1036.

27. Meade HM, Long SR, Ruvkun GB, Brown SE, Ausubel FM: Physical and genetic characterization of symbiotic and auxotrophic mutants of 
Rhizobium meliloti induced by transposon Tn5 mutagenesis. J Bacteriol 1982, 149(1):114-122.

28. Casse F, Boucher C, Julliot JS, Michel M, Dénarié J: Identification and Characterization of Large Plasmids in Rhizobium meliloti using Agarose Gel Electrophoresis. J Gen Microbiol 1979, 113(2):229-242.

29. Pobigaylo N, Wetter D, Szymczak S, Schiller U, Kurtz S, Meyer F, Nattkemper TW, Becker A: Construction of a large signature-tagged mini-Tn5 transposon library and its application to mutagenesis of Sinorhizobium meliloti. Appl Environ Microbiol 2006, 72(6):4329-4337.

30. Becker A, Barnett MJ, Capela D, Dondrup M, Kamp PB, Krol E, Linke B, Ruberg S, Runte K, Schroeder BK, Weidner S, Yurgel SN, Batut J, Long SR, Puhler A, Goesmann A: A portal for rhizobial genomes: RhizoGATE integrates a Sinorhizobium meliloti genome annotation update with postgenome data. J Biotechnol 2009, 140(1-2):45-50.

31. Torres MJ, Hidalgo-Garcia A, Bedmar EJ, Delgado MJ: Functional analysis of the copy 1 of the fixNOQP operon of Ensifer meliloti under free-living micro-oxic and symbiotic conditions. J Appl Microbiol 2013, 114(6):1772-1781.

32. Delgado MJ, Bonnard N, Tresierra-Ayala A, Bedmar EJ, Muller P: The Bradyrhizobium japonicum napEDABC genes encoding the periplasmic nitrate reductase are essential for nitrate respiration. Microbiology 2003, 149(Pt 12):3395-3403.

33. García-Plazaola J: Denitrification in lucerne nodules is not involved in nitrite detoxification. Plant Soil 1996, 182:149-155.

34. Bedzyk L, Wang T, Ye RW: The periplasmic nitrate reductase in Pseudomonas sp. strain G-179 catalyzes the first step of denitrification. J Bacteriol 1999, 181(9):2802-2806.

35. Velasco L, Mesa S, Delgado MJ, Bedmar EJ: Characterization of the nirK gene encoding the respiratory, Cu-containing nitrite reductase of Bradyrhizobium japonicum. Biochim Biophys Acta 2001, 1521(1-3):130-134.

36. Mesa S, Velasco L, Manzanera ME, Delgado MJ, Bedmar EJ: Characterization of the norCBQD genes, encoding nitric oxide reductase, in the nitrogen fixing bacterium Bradyrhizobium japonicum. Microbiology 2002, 148(Pt 11):3553-3560.

37. Gomez-Hernandez N, Reyes-Gonzalez A, Sanchez C, Mora Y, Delgado MJ, Girard L: Regulation and symbiotic role of nirK and norC expression in Rhizobium etli. Mol Plant Microbe Interact 2011, 24(2):233-245.

38. Velasco L, Mesa S, Xu CA, Delgado MJ, Bedmar EJ: Molecular characterization of nosRZDFYLX genes coding for denitrifying nitrous oxide reductase of Bradyrhizobium japonicum. Antonie Van Leeuwenhoek 2004, 85(3):229-235.

39. Aida T, Hata S, Kusunoki H: Temporary low oxygen conditions for the formation of nitrate reductase and nitrous oxide reductase by denitrifying Pseudomonas sp. G59. Can J Microbiol 1986, 32(7):543-547.

40. Bergaust L, Shapleigh J, Frostegard A, Bakken L: Transcription and activities of NOx reductases in Agrobacterium tumefaciens: the influence of nitrate, nitrite and oxygen availability. Environ Microbio/ 2008, 10(11):3070-3081.

41. Bergaust $L$, Mao $Y$, Bakken LR, Frostegard A: Denitrification response patterns during the transition to anoxic respiration and posttranscriptional effects of suboptimal $\mathrm{pH}$ on nitrous oxide reductase in Paracoccus denitrificans. Appl Environ Microbiol 2010, 76(19):6387-6396.

42. Nadeem S, Dorsch P, Bakken LR: The significance of early accumulation of nanomolar concentrations of NO as an inducer of denitrification. FEMS Microbiol Ecol 2013, 83(3):672-684

43. Beringer JE: R factor transfer in Rhizobium leguminosarum. J Gen Microbiol 1974, 84(1):188-198.

44. Robertsen BK, Aman P, Darvill AG, McNeil M, Albersheim P: The structure of acidic extracellular polysaccharides secreted by Rhizobium leguminosarum and Rhizobium trifolii. Plant Physiol 1981, 67(3):389-400.

45. Vargas C, McEwan AG, Downie JA: Detection of c-type cytochromes using enhanced chemiluminescence. Anal Biochem 1993, 209(2):323-326.

46. Nicholas DJD, Nason A: Determination of nitrate and nitrite. In Methods in Enzymology, Volume III. Edited by Colowick SP, Kaplan NO. London: Academic Press; 1957:974-977.

47. Zhang X, Broderick M: Amperometric detection of nitric oxide. Mod Asp Immunobiol 2000, 1(4):160-165.
48. Sambrook J, Fritsch EF, Maniatics T: Molecular cloning: a laboratory manual. New York: Cold Spring Harbor Laboratory Press; 1989.

49. Glenn SA, Gurich N, Feeney MA, Gonzalez JE: The ExpR/Sin quorum-sensing system controls succinoglycan production in Sinorhizobium meliloti. J Bacterio/ 2007, 189(19):7077-7088.

50. Krol E, Becker A: Global transcriptional analysis of the phosphate starvation response in Sinorhizobium meliloti strains 1021 and 2011. Mol Genet Genomics 2004, 272(1):1-17.

doi:10.1186/1471-2180-14-142

Cite this article as: Torres et al:: Genetic basis for denitrification in Ensifer meliloti. BMC Microbiology 2014 14:142.

\section{Submit your next manuscript to BioMed Central and take full advantage of:}

- Convenient online submission

- Thorough peer review

- No space constraints or color figure charges

- Immediate publication on acceptance

- Inclusion in PubMed, CAS, Scopus and Google Scholar

- Research which is freely available for redistribution

Submit your manuscript at www.biomedcentral.com/submit
C Biomed Central 